Columbia Law School

Scholarship Archive

2008

\title{
Symposium on Pursuing Racial Fairness in Criminal Justice: Twenty Years after McCleskey v. Kemp
}

Jeffrey Fagan

Columbia Law School, jfagan@law.columbia.edu

Mukul A. Bakhshi

mab2139@columbia.edu

Follow this and additional works at: https://scholarship.law.columbia.edu/faculty_scholarship

Part of the Criminal Law Commons, and the Law and Race Commons

\section{Recommended Citation}

Jeffrey Fagan \& Mukul A. Bakhshi, Symposium on Pursuing Racial Fairness in Criminal Justice: Twenty Years after McCleskey v. Kemp, Columbia Human Rights LaW ReVIEW, Vol. 39, P. 1, 2007; Columbia PubliC LAW RESEARCH PAPER No. 08-165 (2008).

Available at: https://scholarship.law.columbia.edu/faculty_scholarship/1514

This Working Paper is brought to you for free and open access by the Faculty Publications at Scholarship Archive. It has been accepted for inclusion in Faculty Scholarship by an authorized administrator of Scholarship Archive. For more information, please contact scholarshiparchive@law.columbia.edu. 


\section{Columbia Law School}

Public Law \& Legal Theory Working Paper Group

Paper Number 08-165

\section{SYMPOSIUM ON PURSUING RACIAL FAIRNESS IN CRIMINAL JUSTICE: \\ TWENTY YEARS AFTER MCCLESKEY v. KEMP}

BY:

PROFESSOR JEFFREY FAGAN

COLUMBIA LAW SCHOOL

- AND -

MUKUL A. BAKHSHI

COLUMBIA LAW SCHOOL

This paper can be downloaded free of charge from the Social Science Research Network at: http://ssrn.com/abstract $=1095320$ 


\title{
SYMPOSIUM ON PURSUING RACIAL FAIRNESS IN CRIMINAL JUSTICE: TWENTY YEARS AFTER MCCLESKEY v. KEMP*
}

MARCH 2-3, 2007

INTRODUCTION

\section{NEW FRAMEWORKS FOR RACIAL EQUALITY IN THE CRIMINAL LAW}

\author{
Jeffrey Fagan**
}

Mukul Bakhshi***

\begin{abstract}
This Symposium, "Pursuing Racial Fairness in the Administration of Justice: Twenty Years After McCleskey v. Kemp," was conceived and inspired by Theodore Shaw, Director-Counsel and President of the NAACP Legal Defense and Educational Fund, Inc. Ted Shaw and his staff worked with Columbia Law School Professor Jeffrey Fagan to recruit an outstanding group of scholars and activists who met on March 2-3, 2007 to hear and comment on the articles appearing in this Symposium. In addition to the authors whose work appears in this issue, many others made important contributions to the Symposium through their commentaries and presentations. These include Christina Swarns, Cathleen Price, Dean Charles Boger, Lawrence C. Marshall, Dick Burr, George Kendall, Charles Ogletree, Kendall Thomas, Bryan Stevenson, Steven Hawkins, Wayne McKenzie, State Senator Rodney Ellis, David Singleton, and Gara LaMarche. We are grateful to all of them for their invaluable contributions.

Professor of Law and Public Health, and Co-Director, Center for Institutional and Social Change, Columbia Law School.

**** J.D. candidate, Columbia Law School.
\end{abstract}




\section{A SOMBER ANNIVERSARY}

This year marked the twentieth anniversary of the U.S. Supreme Court's decision in McCleskey $v$. Kemp, ${ }^{1}$ a case whose ramifications for the pursuit of racial equality within criminal justice are still felt today. McCleskey set an impossibly high bar for constitutionally-based challenges seeking fundamental racial fairness in capital punishment. The McCleskey court avoided the "racial blindsight", or color-blindness, that characterizes much contemporary civil rights and criminal justice jurisprudence. ${ }^{2}$ Instead, the Court embraced the reality that prosecutors craft pretextual, race-neutral explanations for selective prosecutions of death sentences, as well as compelling evidence of the racially skewed and biased patterns of their aggregate decisions. ${ }^{3}$ But the McCleskey decision went even further: it created a jurisprudential climate that shifted and increased the burden on defendants seeking constitutional relief from discriminatory and biased decisions at every step of the criminal justice process, from arrest to conviction and punishment.

McCleskey had two intersecting messages, and the consequences of each fell squarely on the backs and bodies of African Americans in the criminal justice system. First, McCleskey demanded a showing of specific racial animus even when defendants could show a strong pattern and practice of discrimination in discretionary decisions by prosecutors and other legal actors. ${ }^{4}$ In the McCleskey briefs, Professor David Baldus and his colleagues provided strong empirical evidence of the racially discriminatory pattern of death sentencing in Georgia during the years between the reinstatement of capital punishment in 1973, upheld in Gregg v. Georgia in 1976, and 1979. Baldus et al. identified systemic racial disparities in the decision to seek the death penalty and in the decision by juries to

1. McCleskey v. Kemp, 481 U.S. 279 (1987) (affirming death sentence and holding that evidence of racial disparity in death penalty cases was insufficient to prove a violation of the Equal Protection Clause or the Eighth Amendment).

2. Andrew Taslitz, Racial Blindsight: The Absurdity of Color-Blind Criminal Justice, 5 Ohio St. J. Crim. L. (forthcoming 2007) (manuscript at 3-4, on file with author) (discussing the judicial aversion to race-specific analyses in constitutional criminal law and explaining how the psychological phenomenon of racial blindsight causes people to be blind to the existence of racial biases in society while at the same time subconsciously aware that these biases exist).

3. McCleskey, 481 U.S. at 314 .

4. Id. at 292-93. 
return capital verdicts: defendants who killed whites were 4.3 times more likely to receive a death sentence than those who killed African Americans. $^{5}$

Even while accepting the Baldus research as correct, however, the high court rejected Warren McCleskey's Equal Protection claim. As Justice Powell stated, "To prevail under the Equal Protection Clause, McCleskey must prove that the decisionmakers in his case acted with discriminatory intent." ${ }^{\prime 6}$ Of course, absent some type of indiscreet comment by a prosecutor or judge that provides "smoking-gun" proof of discriminatory intent, the evidentiary threshold required by McCleskey was then and still is virtually insurmountable. Moreover, the insertion of an individualized intent requirement freed the state of responsibility for racially disparate outcomes resulting from the historical legacy of racial oppression and from unconscious racial biases.

The second prong of McCleskey gained less attention but was equally pernicious. The Court said it would tolerate errors in criminal justice, ${ }^{7}$ without acknowledging their prevalence, their possible consequences, their racial skew, or other biases in the patterns of error. Even when death is the outcome, the Court accepted the prospect of error: "There can be 'no perfect procedure for deciding in which cases governmental authority should be used to impose death."'8 Thus, the Court decided that structural imperfections, however racially skewed they may be, were not just inevitable, but were a necessary evil to preserve capital punishment. Banking on a "super due process" safety net to regulate and prevent racially skewed decisions, the $M c$ Cleskey court dismissed the demand for perfection and fairness, even when the consequences of error are death. "Given these safeguards already inherent in the imposition

5. Baldus collected data on every death sentence in Georgia from 1973 to 1979, and statistically controlled for 39 non-racial variables such as the defendant's age, criminal record, motives, and mode of killing, to determine the race-specific probability of receiving a death sentence. See David C. Baldus et al., Equal Justice and the Death Penalty: A Legal and Empirical Analysis 319-20 (1990) [hereinafter Baldus Study]. These racial biases in Georgia persist today, as revealed in a recent series on the administration of the death penalty in Georgia, published in the Atlanta Journal-Constitution. See Bill Rankin et al., An AJC Special Report; A Matter of Life or Death: Death Still Arbitrary, Atlanta J. Const., Sept. 23, 2007, at A1.

6. McCleskey, 481 U.S. at 279.

7. Id. at 313 (quoting Zant v. Stephens, 462 U.S. 862, 884 (1983)).

8. Id. 
and review of capital sentences, the dissent's call for greater rationality is no less than a claim that a capital punishment system cannot be administered in accord with the Constitution."

The Court then invoked a form of "racial blindsight" by declaring that Eighth Amendment challenges based on claims similar to McCleskey's were so elastic that they could extend to other arbitrary variables like facial characteristics or physical attractiveness: "The Constitution does not require that a State eliminate any demonstrable disparity that correlates with a potentially irrelevant factor in order to operate a criminal justice system that includes capital punishment."10 In essence, the Court held that it would not find a constitutional violation because it would jeopardize not just capital punishment, but the functioning of the criminal justice system:

McCleskey's claim, taken to its logical conclusion, throws into serious question the principles that underlie our entire criminal justice system. . . . Thus, if we accepted McCleskey's claim that racial bias has impermissibly tainted the capital sentencing decision, we could soon be faced with similar claims as to other types of penalty. ${ }^{11}$

Rather than confront the difficult issues raised by the disparate racial impact of sentencing, and the wholesale reconsideration of the criminal justice policies that would ensue, the Court chose to tolerate widespread errors and racial disparities, finding no offense to the Constitution in these patterns. In so doing, the McCleskey Court reified the institutional norms and structural biases that sustain racial imbalances in all stages of the criminal law.

The McCleskey Court, in refusing to consider the impact of race on juror and prosecutorial decisions, allowed these norms, preferences, and biases to play a significant role in sentencing without any constitutional remedy. ${ }^{12}$ One consequence of racially

\footnotetext{
9. $\quad$ Id. at 315 n.21.

10. Id. at 319 .

11. Id. at $314-15$.

12. The institutionalization of preferences and biases into the everyday practices of a prosecution office that often sought the death penalty was revealed by the public disclosure of a training video from 1986 that described in detail techniques for discriminating in jury selection, including maintenance of a running tally of the race of the venire panel and the invention of pre-textual reasons for exercising peremptory challenges. The tape, created by then-assistant
} 
"cleansed" juries is a significantly greater likelihood of death verdicts for African Americans. ${ }^{13}$ Professor Jennifer Eberhardt and colleagues used experimental methods to expose the moving parts of this process. Re-analyzing the Baldus database of Philadelphia-area death-eligible cases,${ }^{14}$ this study shows that among cases with a black defendant and white victim, $57.5 \%$ of 'stereotypically black' defendants received death sentences in comparison to $24.4 \%$ of defendants with less stereotypically black features. ${ }^{15}$ When both the defendant and victim were African-American, however, there was no statistical disparity in death sentences attributable to the racial features. ${ }^{16}$ The cascades of black incarceration and other visible manifestations of increased black presence in criminal justice institutions $\mathrm{s}^{17}$ may have created an assumption of black criminality that leads prosecutors and jurors to be especially punitive.

district attorney Jack McMahon of the Philadelphia County District Attorney's Office, included such statements as: "Let's face it, . . . there's the blacks from the low-income areas[,] . . . you don't want those people on your jury." Notes from one of the lawyers present at the jury selection training program-conducted by another prosecutor several years after the videotaped training-disclosed that prosecutors were again taught such things as, "The ideal jury, 12 Archie Bunkers, will convict on little evidence." See David C. Baldus et al., The Use of Peremptory Challenges in Capital Murder Trials: A Legal and Empirical Analysis, 3 U. Pa. J. Const. L. 3 (2001) (studying the use of peremptory challenges by prosecutors and defense counsel in Philadelphia County, Pennsylvania; using the tape to help define the groups of venire persons targeted). Baldus et al. showed that during 23 homicide prosecutions, the trial prosecutor struck black jurors 3.3 times more frequently than white jurors, and 10 times more frequently in the case actually before the court. Id. at 58. This study also reported a statistically significant relationship between the racial composition of Philadelphia death penalty juries and the disproportionate rate at which these juries were sentencing AfricanAmerican defendants to death. Id. at 84-95.

13. Id. at 84-95.

14. Jennifer L. Eberhardt et al., Looking Deathworthy: Perceived Stereotypicality of Black Defendants Predicts Capital-Sentencing Outcomes, 17 Psychol. Sci. 383, 384 (2006) (analyzing data from the study published by David C. Baldus et al., Racial Discrimination and the Death Penalty in the Post-Furman Era: An Empirical and Legal Overview, With Recent Findings from Philadelphia, 83 Cornell L. Rev. 1638 (1998), (showing the importance of stereotyped racial features in jurors' attributions of culpability and "deathworthiness")).

15. Eberhardt et al., id. at 385.

16. Id. at 385 .

17. See Marc Maurer, Race to Incarcerate 118-26 (2d ed. 2006) (identifying sources of exponential growth in the U.S. prison population and offering explanations for disparities in imprisonment of African Americans); Michael Tonry, Malign Neglect: Race, Crime and Punishment in America 28-31, 49-68 
The racial skew in death verdicts reflects in no small part the accumulation of selective prosecutions and the systematic application of discretion freed from constitutional regulation and oversight. But there also are structural features of criminal law and criminal justice that adversely affect African Americans and other racial and ethnic minorities. Animated by the War on Drugs, the racialized selectiveenforcement of drug laws and the structured sentencing practices in these laws are primary forces in the production of large racial disparities in incarceration. ${ }^{18}$ The costs of the War on Drugs, with its harsh sentencing regimes, largely fall on minority communities and bolster societal stereotypes of minority criminality. Although whites have higher rates of drug use, three-fifths of drug offenders imprisoned in 1998 were African-American. ${ }^{19}$ That result partly occurs because of the vicious cycle of increased police enforcement and incarceration that is concentrated largely in poor, predominantly minority neighborhoods. ${ }^{20}$ "Incarceration begets more incarceration, and incarceration also begets more crime, which, in turn, invites more aggressive enforcement, which then resupplies incarceration. ${ }^{\prime 1}$ In New York City, for instance, the adoption of "zero tolerance" policies and aggressive police patrol initiatives like "Operation Condor," which involved the use of police overtime for buy-and-bust operations in primarily minority neighborhoods, have accelerated minority imprisonment at a time of declining crime rates. ${ }^{22}$

(1996) (examining the causes of racial disparities in the criminal justice system and showing the centrality of drug sentencing statutes to the growth of the U.S. prison population).

18. See Tonry, supra note 17, at 81-83. See also R. Richard Banks, Beyond Profiling: Race, Policing, and the Drug War, Stan. L. Rev. (forthcoming 2008); Steven Wu, The Secret Ambition of Racial Profiling, 115 Yale L.J. 491, 498 (2005); David J. Harris, Profiles in Injustice: Why Racial Profiling Cannot Work 12 (2002); William J. Stuntz, Race, Class and Drugs, 98 Colum. L. Rev. 1795 (1998); Jeffrey Fagan et al., Reciprocal Effects of Crime and Incarceration in New York City Neighborhoods, 30 Fordham Urb. L. J. 1551 (2003); Randall Kennedy, Race, Crime and Law (1997).

19. Dorothy E. Roberts, The Social and Moral Cost of Mass Incarceration in African American Communities, 56 Stan. L. Rev. 1271, 1275 (2004).

20. Fagan et al., supra note 18. See also Leonard Saxe et al., The Visibility of Illicit Drugs: Implications for Community-Based Drug Control Strategies, 91 Amer. J. Pub. Health 1987, 1991 (2001) (showing few differences in drug selling between whites and non-whites, but greater police enforcement in poorer and more disadvantaged neighborhoods).

21. Id. at 1554 .

22. Id. at $1563-66$. 
We see today these legacies of McCleskey in drug enforcement and incarceration, as well as on death row. African Americans and Hispanics are more likely to be stopped by the police, and searched and arrested if stopped..$^{23}$ African Americans are overrepresented in prisons relative to the rate at which they commit crime. ${ }^{24}$ Their sentences are longer, reflecting sentencing laws which, in most states, mandate long spells of incarceration for violent crimes and drug offenses with little room for modifications or exceptions in individual circumstances. ${ }^{25}$ For capital crimes, they are more likely to receive the death penalty. ${ }^{26}$ In fact, the racial disparities in the

23. See, e.g., Matthew R. Durose et al., U.S. Dep't of Justice, Bureau of Justice Statistics, Contacts Between Police and the Public, 20051 (2005), http://www.ojp.usdoj.gov/bjs/pub/pdf/cpp05.pdf (finding that for the period 200205 , Hispanics and blacks were more likely to be searched than whites at a traffic stop). See also Andrew Gelman et al., An Analysis of the NYPD's Stop-and-Frisk Policy in the Context of Claims of Racial Bias, 102 J. Am. Stat. Ass'n 803 (2007) (finding that persons of African and Hispanic descent were subject to more pedestrian stops by New York police officers than whites even after controlling for precinct variability and race-specific estimates of crime participation).

24. Becky Pettit \& Bruce Western, Mass Imprisonment and the Life Course: Race and Class Inequality in U.S. Incarceration, 69 Am. Soc. Rev. 151 (2004). See also Alfred J. Blumstein, On the Racial Disproportionality of U.S. Prison Populations, 73 J. Crim. L. \& Criminology 1259 (1982) (reporting higher incarceration rates for African Americans based on comparisons of ratio of racespecific clearance rates to race-specific incarceration rates); Alfred Blumstein, Race and Criminal Justice, in America Becoming: Racial Trends and Their Consequences, Volume II (Neil Smelser et al. eds., 2001).

25. Tonry, supra note 17, at 41-44.

26. See, e.g., John Donohue, Capital Punishment in Connecticut, 19732007: A Comprehensive Evaluation from 4,600 Murders to One Execution 1 (2007), http://apublicdefender.com/wp-content/uploads/2007/12/34239635.pdf; Raymond Paternoster et al., Justice by Geography and Race: The Administration of the Death Penalty in Maryland, 1978-99, 4 Margins 1 (2004) (using multivariate regression analysis to show racial preferences for white-victim homicides in death-seeking by prosecutors in Maryland based on analysis of 1,311 death-eligible cases from 1978 to 1999). Prosecutors filed death notices in 353 of the 1,311 death-eligible cases, which were $21.85 \%$ of the state's 6000 murders during the study interval. Id. at 18-20. Death notices were withdrawn in 140 cases. $I d$. at 20 . White-victim cases accounted for $44 \%$ of the death-eligible cases, but accounted for $66 \%$ of the death notices. Id. at 25 . Of the 76 cases concluding in a death sentence, $80 \%$ were white-victim cases. Id. Prosecutors filed death notices 2.5 times more often for white-victim cases than black-victim cases; death sentences were more than five times more likely in white-victim homicides. Id. at 26. After controlling for offense, offender, victim and county characteristics, Paternoster et al. showed that prosecutors filed death notices 1.7 times more often against defendants who were accused of murdering a white victim. $I d$. at 
selection of cases for capital prosecution are no less today than they were nearly three decades ago during the Baldus Study in Georgia that was part of the McCleskey challenge. ${ }^{27}$ Not only are African Americans convicted of killing whites more likely to be selected for capital prosecution, they are more likely to be executed if they kill a white person than if they kill someone of another race. ${ }^{28}$ We now know the serious consequences of these disparities: the same racial factors that underlie disparities in death sentencing-interracial homicides committed by black defendants and the ratios of blackvictim and white-victim homicides-also are implicated in the production of the very high rate of reversals in death sentences. ${ }^{29}$

The harsher treatment of African Americans and other racial and ethnic minorities cannot be dismissed solely as a matter of racial differentials in crime rates. Modern empirical research shows that these differences persist more as a matter of selective enforcement

37. Black defendants who kill white victims were more than twice as likely to receive death notices, 2.5 times more likely to be sentenced to death, and 3.6 times more likely to be executed compared to black defendants who kill black victims. Id.; see also Michael Millemann \& Gary Christopher, Preferring White Lives: The Racial Administration of the Death Penalty in Maryland, 5 U. Md. L.J. Race, Religion, Gender \& Class 1 (2005) (explaining the significance of the Paternoster dataset in highlighting the racially discriminatory application of the death penalty in Maryland); Rankin et al., supra note 5.

27. See David C. Baldus et al., Race and Proportionality Since McCleskey v. Kemp (1987): Different Actors with Mixed Strategies of Denial and Avoidance, 39 Colum. Hum. Rts. L. Rev. 143, 160-61 (2007); Rankin et al., supra note 5; Paternoster et al., supra note 26.

28. David Jacobs, Zhenchao Qian, Jason Carmichael, and Stephanie L. Kent, Who Survives on Death Row? An Individual and Contextual Analysis, 72 Amer. Soc. Rev. 610 (2007) (showing statistically that African Americans convicted of killing whites are more likely than other murderers to receive a death sentence and more likely to be executed, and that African Americans on death row for killing nonwhites are less likely to be executed than other condemned prisoners).

29. James S. Liebman et al., A Broken System, Part II: Why There Is So Much Error in Capital Cases, and What Can Be Done About It at 2 (2002), http://www2.law.columbia.edu/brokensystem2/report.pdf (showing that $68 \%$ of all death sentences between 1973 and 1995 were reversed due to serious errors, and using multivariate regression analysis to show that the reversal rates are higher in states where the ratio of white homicide victims to black homicide victims is higher; the same analysis showed that reversal rates are higher in states that have a larger black population). See also Andrew Gelman et al., A Broken System: The Persistent Patterns of Reversals of Death Sentences in the United States, $1 \mathrm{~J}$. Emp. Legal Studies 209, 209 (2004). 
than crime-rate differences. ${ }^{30}$ Also, both trial and appellate courts are less willing to address racial imbalances in the criminal justice system. Instead, courts give strong deference to legal actors, and often cite a balancing test of the threat of crime against closer scrutiny of local practices. ${ }^{31}$

\section{The CONTEXT}

Both the past and future of McCleskey require careful analysis of the specific social and historical context of the decision. The case was decided just a few years into the dawn of a jurisprudential era that was less receptive (if not hostile) to racebased challenges in both criminal and civil law. As Robert Stroup shows in his contribution to the Symposium, the decision also came at the conclusion of an era of intense activism and conflict in American society over racial inequality and race discrimination. ${ }^{32}$ McCleskey was one of the first decisions in an ongoing historical process that has expanded the discretion of legal decision-makersfrom police through corrections officials-and simultaneously insulated them from meaningful constitutional challenges. ${ }^{33}$

30. See, e.g., Gelman et al., supra note 23; Ronald Weitzer \& Steven A. Tuch, Race and Policing in America (2006); Saxe et al., supra note 20.

31. See, e.g., Whren v. United States, 517 U.S. 806 (1996) (finding that pretextual stops of motor vehicles by police are permissible so long as the officer has probable cause that a crime may have occurred); Brown v. City of Oneonta, 195 F.3d 111, 116-19 (2d Cir. 1999), amended and vacated 221 F.3d 329, 334-36 (2d Cir. 2000). The tortured procedural history of Brown shows the tensions that arise when the courts apply race-blind analyses to criminal law enforcement when its moving parts are transparently and facially racial. See 221 F.3d at 329; 195 F.3d at 111. The district court in Brown issued four separate opinions after both sides to the dispute made several motions for reconsideration. See $221 \mathrm{~F} .3 \mathrm{~d}$ at 335-36 (recounting the procedural history leading to amended opinion). On appeal, a three-judge panel of the Second Circuit dismissed the plaintiffs' $§ 1983$ claims under the Equal Protection Clause and, with regard to several plaintiffs, denied their Fourth Amendment claims. See 195 F.3d at 123. The following year, the panel abruptly reversed itself on several Fourth Amendment claims while adhering to its decision that the police sweep did not involve any discriminatory intent. See 221 F.3d at 336.

32. Robert H. Stroup, The Political, Legal \& Social Context of the McCleskey Habeas Litigation, 39 Colum. Hum. Rts. L. Rev. 74 (2007).

33. See William J. Stuntz, The Pathological Politics of Criminal Law, 100 Mich. L. Rev. 505, 558 (2001) ("The commitment to prosecutorial discretion rules out aggressive equal protection review of charging decisions, the kind of review that would seek out and correct enforcement disparities among different 
Racial profiling, a central strategy in the War on Drugs, has generated numerous constitutional challenges that have been rebuffed almost without exception. ${ }^{34}$ The U.S. Supreme Court has shown its preference for protecting prosecutorial and law enforcement discretion rather than limiting the racially disparate exercise of that discretion. ${ }^{35}$ In United States $v$. Armstrong, for example, the Supreme Court reversed a decision permitting discovery to prove racially selective prosecution for crack cocaine. ${ }^{36}$ Despite evidence that all twenty-four prosecutions in the local area were of African-American defendants, the Court determined that the defendants had failed to show that the government declined to prosecute similarly situated defendants of another race. ${ }^{37}$ In Whren $v$. United States, the Court held that a police officer's subjective reasons for stopping a car were irrelevant to determining the constitutionality of that stop; rather, the stop's constitutionality should be considered from the perspective of a reasonable officer considering the circumstances of the stop. ${ }^{38}$ Four years later, in Illinois $v$. Wardlow, the Court held that unprovoked flight in a highcrime area established reasonable suspicion to legitimize the police officer's stop of the defendant. ${ }^{39}$ Taken together, the Court's rulings

population groups and would bar irregular and sporadic enforcement altogether.").

34. See R. Richard Banks, Beyond Profiling: Race, Policing, and the Drug War, Stan. L. Rev. (forthcoming 2008); Steven Wu, The Secret Ambition of Racial Profiling, 115 Yale L.J. 491, 498 (2005); David J. Harris, Profiles in Injustice: Why Racial Profiling Cannot Work 12 (2002). See also William J. Stuntz, Race, Class and Drugs, 98 Colum. L. Rev. 1795 (1998); Kevin R. Johnson, The Story of Whren v. United States: The Song Remains the Same, in Race and Law Stories (Devon Carbado \& Rachel F. Moran eds., 2007).

35. In these cases, even when race is not a factor in the litigation, the weight of the decision more often falls on racial minorities. See, e.g., Bond v. United States, 529 U.S. 334, 339 (2000) (holding that border agent's squeezing of a bus passenger's soft luggage violated the Fourth Amendment). But the Bond doctrine has been often limited in scope. See, e.g., United States v. Flowal, 234 F.3d 932, 935 (6th Cir. 2000) (holding that because defendant fit a drug courier profile and consented to the search, Bond is inapplicable). Race neutrality in criminal law is a fiction, and often the indicia of race are substituted for race itself.

36. United States v. Armstrong, 517 U.S. 456, 462 (1996).

37. Id. at 465 .

38. Whren v. United States, 517 U.S. 806, 814 (1996). See Johnson, supra note 34 .

39. Illinois v. Wardlow, 528 U.S. 119, 124 (2000) (“[O]fficers are not required to ignore the relevant characteristics of a location in determining 
allow officers to consider the criminality of the location-which often is a proxy for minority neighborhoods-thereby lowering the bar for establishing reasonable suspicion for a search: upon review, the police officer's intent is dismissed as irrelevant, and evidence of racial discrimination in prosecution is required to meet an extraordinarily high threshold. ${ }^{40}$

The Supreme Court has been far more receptive, however, to efforts to eliminate racial discrimination in the jury selection process, drawing a clear distinction between the importance of race in Fourteenth and Sixth Amendment challenges. In Batson v. Kentucky, the Court rejected the use of peremptory challenges by prosecutors to exclude African Americans from a jury pool and allowed defendants to establish a prima facie case of systematic minority exclusion to compel an explanation from prosecutors. ${ }^{41}$ The Supreme Court has robustly attempted to protect voir dire from racial discrimination by prosecutors, extending, for instance, the Batson doctrine to allow defendants to challenge the race-based exclusion of potential jurors of a different race through peremptory challenges. ${ }^{42}$ In Miller-El $v$. Dretke, the Supreme Court intervened in two separate cases to give the defendant the opportunity to challenge the peremptory exclusion of over ninety percent of the African Americans in the jury pool. ${ }^{43}$ In granting the defendant's habeas petition, the Supreme Court rejected the prosecutor's pretextual explanations for the disparate conclusions "which reek[ed] of afterthought." discrimination in juror selection-especially when contrasted with its timidity in addressing discrimination in other areas of criminal

whether the circumstances are sufficiently suspicious to warrant further investigation.").

40. See, e.g., Jeffrey Fagan \& Garth Davies, Street Stops and Broken Windows: Terry, Race and Disorder in New York City, 28 Fordham Urb. L.J. 457, 477 (2000) (showing that police officers focused Terry stops in New York City's poorest neighborhoods with the highest minority concentrations, independent of these neighborhoods' crime rates, evidently basing suspicion on their assumption of the fungibility of minority population concentration in a neighborhood and an elevated rate of crime).

41. Batson v. Kentucky, 476 U.S. 79, 97 (1986).

42. Powers v. Ohio, 499 U.S. 400, 409 (1991) (drawing on Batson to hold that the Equal Protection Clause prohibits a prosecutor from using the State's peremptory challenges to exclude otherwise qualified and unbiased persons from the petit jury solely on the basis of race).

43. Miller-El v. Dretke, 545 U.S. 231 (2005).

44. Id. at 246 . 
justice-can leverage the increased diversity of juries into the potential for more equitable criminal justice outcomes, a dynamic discussed by Professor Sherri Lynn Johnson in her contribution to this Symposium. ${ }^{45}$ Moreover, the prohibition against racially discriminatory peremptory challenges might alter prosecutorial heuristics in choosing whether to pursue the death penalty in given cases. However, the Batson compromise is threatened by Snyder $v$. Louisiana ${ }^{46}$, where the use of non-racial factors in voir dire can mask and mitigate facial evidence of racial bias in the use of preemptory challenges. In Snyder, the masking of racial bias behind opaque and vague race-correlated rationales cynically exploits the Batson standards and contradicts the Court's holding in Miller-El.

These opinions resulted in part from changes in the Supreme Court's composition since McCleskey, constituting a court whose jurisprudential and ideological leanings departed sharply from those of the Court just a generation earlier. The Court became even more deferential to state actors than its predecessors who decided McCleskey, substituting procedural limitations for a substantive analysis of the wrongs a party sought to redress. ${ }^{47}$ Moreover, lower courts have also increasingly deferred to the states rather than exerting the authority to protect the integrity of criminal justice

45. Sheri Lynn Johnson, Litigating for Racial Fairness After McCleskey v. Kemp, 39 Colum. Hum. Rts. L. Rev. 178 (2007).

46. Snyder v. Louisiana, 942 So.2d 484 (La. 9/6/06), cert. granted, 127 S.Ct. 3004 (U.S. June 25, 2007) (No. 06-10119). Snyder appealed his capital conviction, claiming discriminatory intent and racial bias by the prosecutor in the use of peremptory challenges to remove five African-American jurors. Synder also claimed that the prosecutor's referencing of the O.J. Simpson case during closing arguments provided further evidence of discriminatory intent in the use of peremptory challenges. Snyder further alleged an apparent racial double standard in the disqualification process, illustrated by the prosecutor's disparate language used to question black and white prospective jurors. Moreover, the one African-American juror initially accepted by the prosecution, a student teacher, was later removed supposedly because his academic duties might cause him to rush through deliberations. But the prosecutor accepted a white juror, a contractor, who had home-building projects to complete and an ill wife, factors that obviously would have similar impacts on deliberations.

47. See, e.g., Lawrence v. Florida, 127 S.Ct. 1079, 1086 (2007) (holding that one-year statute of limitations for seeking federal habeas corpus relief is not tolled while awaiting certiorari from the U.S. Supreme Court); Hein v. Freedom of Religion Foundation, 127 S.Ct. 2553 (2007) (holding that taxpayer has no standing to challenge "faith based initiatives" as violating the Establishment Clause). 
processes, even when sidestepping procedural questions. ${ }^{48}$ For instance, in Fry $v$. Pliler, the Court employed a more deferential standard for assessing constitutional errors in a federal habeas corpus review of a state criminal trial because of principles of comity and federalism, even where the state court had not reviewed those constitutional claims. ${ }^{49}$

Despite the gains in the jury cases, formidable barriers to bringing race-based equal-protection claims in the criminal law (and other areas of law and social policy) still exist today. But as in the era leading to Brown fifty years ago, these constitutional and procedural obstacles pose challenges that legal scholars and advocates are mobilizing to defeat. While challenges akin to McCleskey are unlikely to succeed in the current jurisprudential climate, other legal and social policy initiatives are underway to address the failures of the criminal justice system.

For example, both before and after the attacks of September 11th, litigation opposing racial profiling led to a series of consent decrees and legislative measures prohibiting such activity. ${ }^{50}$ Racial data collection policies pursuant to these judicial and legislative initiatives, moreover, often revealed in stark detail the unwarranted disparities in police stops. ${ }^{51}$ Because many of these law enforcement practices involve stopping innocent individuals, bringing cases against racial profiling and other practices that produce disparate racial impacts at the "point of entry" into the criminal justice system can be useful in creating sympathetic profiles of racial discrimination that can shift public opinion. Some state courts have also been receptive to providing remedies for racially disparate practices. ${ }^{52}$

Concerns about arbitrariness in the administration of the death penalty, including concerns about racial fairness, have led at

48. This worked both ways, as in Atkins v. Virginia, 536 U.S. 304, 315-16 (2002), when the Court recognized preferences of the majority of states to prohibit execution of the mentally retarded. Also, the Court recognized a consensus against executing juveniles in Roper v. Simmons, 543 U.S. 551, 552-53 (2005).

49. $\quad$ Fry v. Pliler, 127 S.Ct. 2321, 2325 (2007).

50. Brandon Garrett, Remedying Racial Profiling, 33 Colum. Hum. Rts. L. Rev. 41 (2001); David A. Harris, Good Cops: The Case for Preventive Policing (2005).

51. See Racial Profiling Data Collection Resource Center, http://www.racial profilinganalysis.neu.edu/ (last visited Dec. 20, 2007).

52. David Rudovsky, Litigating Civil Rights Cases to Reform Racially Biased Criminal Justice Practices, 39 Colum. Hum. Rts. L. Rev. 97, 118 (2007). 
least nineteen states to use proportionality review to ensure that death sentences are not arbitrarily imposed. ${ }^{53}$ Proportionality review typically compares the facts of the case at bar either to other deatheligible cases that were not selected for prosecution or to a smaller pool of cases where the death sentence was actually imposed. Despite such inclusion of proportionality review in the majority of death penalty jurisdictions, states have sought even stronger safeguards against arbitrariness. ${ }^{54}$ Several states have established commissions to study the effectiveness, fairness, and race-neutrality of their death penalty statutes and procedures. ${ }^{55}$ These commissions have

53. Proportionality review is required by statute in 19 states: Alabama, Delaware, Georgia, Kentucky, Louisiana, Mississippi, Missouri, Montana, Nebraska, New Hampshire, New Jersey, New Mexico, New York, North Carolina, Ohio, South Carolina, South Dakota, Tennessee, and Washington. Ala. Code $\S$ 13A-5-53(b)(3) (1981); Del. Code Ann. tit. $11 \S 4209$ (g)(2)(a) (1972); Ga. Code Ann. $\S 17-10-35(c)(3)$ (1973); Ky. Rev. Stat. Ann. § 532.075(3)(c) (1976); La. Code Crim. Proc. Ann. art. 905.9.1(c) (1976); Miss. Code Ann. § 99-19-105(3)(c) (1977); Mo. Rev. Stat. § 565.035(3)(3) (1983); Mont. Code Ann. § 46-18-310(1)(c) (1977); Neb. Rev. Stat. § 29-2521.03 (1978); N.H. Rev. Stat. Ann. § 630:5(XI)(c) (1986); N.J. Stat. Ann. § 2C:11-3(e) (1978); N.M. Stat. § 31-20A-4(C)(4) (1979); N.Y. Crim. Proc. Law $\S 470.30(3)(b)(1995) ;$ N.C. Gen. Stat. § 15A-2000(d)(2) (1977); Ohio Rev. Code Ann. § 2929.05(A) (West 1981); S.C. Code Ann. § 16-3-25(C)(3) (1962); S.D. Codified Laws § 23A-27A-12(3) (1979); Tenn. Code Ann. § 39-13-206(c)(1)(D) (1989); Wash. Rev. Code $\S 10.95 .130(2)(b)$ (1981). The Florida Supreme Court has also mandated a proportionality review to ensure the death penalty conforms to state constitutional provisions. See Sinclair v. State, 657 So.2d 1138, 1142 (Fla. 1995) (citing Tillman v. State, 591 So. 2d 167, 169 (Fla. 1991)).

54. In 2007, the North Carolina House of Representatives passed a Racial Justice Act to allow those sentenced to death to challenge prosecutorial decisions that might have been tainted by race. H1291, 2007 Gen. Assem. (N.C. 2007), available at http://www.ncga.state.nc.us/Sessions/2007/Bills/House/HTML/H1291 v1.html. It also passed a proportionality review bill requiring the Supreme Court to compare factually similar cases, as opposed to only examining other cases in which a death sentence was actually imposed. H341, 2007 Gen. Assem. (N.C. 2007), available at http://www.ncga.state.nc.us/Sessions/2007/Bills/House/HTML/ H341v2.html. Neither bill has yet become law.

55. See, e.g., Ariz. Capital Case Comm'n, Capital Case Commission Final Report (2002), http://www.azag.gov/CCC/FinalReport.html; Conn. Comm'n on the Death Penalty, Study Pursuant to Public Act No. 01-151 of the Imposition of the Death Penalty in Connecticut (2003), http://www.cga.ct.gov/olr/Death\%20 Penalty\%20Commission\%20Final\%20Report.pdf; Ill. Comm'n on Capital Punishment, Report of the Governor's Commission on Capital Punishment (2002), http://www.idoc.state.il.us/ccp/ccp/reports/commission_report/complete_ report.pdf; Raymond Paternoster \& Robert Brame, An Empirical Analysis of Maryland's Death Sentencing System with Respect to the Influence of Race and Legal Jurisdiction (2003), http://www.urhome.umd.edu/newsdesk/pdf/finalrep.pdf; 
recommended wide-ranging procedural reforms; a New Jersey commission suggested abolishing the death penalty, ${ }^{56}$ and New Jersey's legislature followed the recommendation and became the first state to repeal its capital punishment statute since Gregg ${ }^{57}$.

Despite the limiting effects of the McCleskey decision, concerns about errors and the possible execution of innocent defendants have led to moratoria on capital punishment in other states, including Illinois and Maryland. ${ }^{58}$ Legislators in Maryland also are debating bills to abolish capital punishment. ${ }^{59}$ The Illinois Governor's Commission on Capital Punishment issued recommendations that extended far beyond death penalty issues. ${ }^{60}$ The Commission recommended the taping of interrogations ${ }^{61}$ the use of sequential photo arrays, ${ }^{62}$ and limitations on the questioning of

Nev. Legislative Commission's Subcomm. to Study the Death Penalty and Related DNA Testing, Work Session Document, 17th Special Session (2002), http://leg.state.nv.us/71st/interim/studies/deathpenalty/WorkSession/Work\%20Se ssion\%20document\%206-14-02.html; Pa. Supreme Court Comm. on Racial \& Gender Bias in the Justice System, Final Report of the Pennsylvania Supreme Court Committee on Racial and Gender Bias in the Justice System (2003), http://www.courts.state.pa.us/Index/Supreme/BiasCmte/FinalReport.pdf; N.J. Death Penalty Study Comm'n, New Jersey Death Penalty Study Commission Report (2007), http://www.njleg.state.nj.us/committees/dpsc_final.pdf; Va. Joint Legislative Audit \& Review Comm'n, Review of Virginia's System of Capital Punishment (2001), http://jlarc.state.va.us/Meetings/December01/capital.pdf. See also United States Dep't of Justice, The Federal Death Penalty System: A Statistical Survey (2000), http://www.usdoj.gov/dag/pubdoc/dpsurvey.html.

56. See New Jersey Death Penalty Study Commission Study Report, supra note 55 , at 2 .

57. Jeremy Peters, Corzine Signs Bill Ending Executions, Then Commutes Sentences of 8, N.Y. Times, Dec. 18, 2007, at B3.

58. Laura Mansnerus, Panel Seeks End to the Death Penalty in New Jersey, N.Y. Times, Jan. 3, 2007, at A1.

59. Id.; see also New Jersey Death Penalty Study Commission Report, supra note 55. In Maryland, two identical death penalty repeal bills are under review by the Maryland House and Senate. H.B. 225, 2007 Reg. Sess., (Md. 2007); S.B. 211, 2007 Reg. Sess., (Md. 2007). Governor Martin O'Malley has indicated that he supports the abolition legislation and would sign it into law. John Wagner \& Eric Rich, O'Malley's Inaction Irks Prosecutors; Delay in New Rules Creates Block, Gives Hope to Law's Opponents, Wash. Post, July 8, 2007, at C11.

60. Report of the Governor's Commission on Capital Punishment (2002), http://www.state.il.us/defender/ccpr_i.html. 37.

61. New Jersey Death Penalty Study Commission Report, supra note 55, at

62. Id. at 47 . 
suspects with mental disabilities. ${ }^{63}$ If implemented, these recommendations would improve fairness throughout the criminal justice system, reducing the likelihood of erroneous convictions.

The events in Florida surrounding the 2000 presidential election raised widespread concerns of minority voter disenfranchisement. ${ }^{64}$ Felon disenfranchisement laws have also been criticized for their role in diluting minority voting power ${ }^{65}$ In 2004, the Ninth Circuit found compelling evidence of racial disparities in the Washington criminal justice system to be sufficient for a trial on the issue of whether felon disenfranchisement violated the Voting Rights Act. ${ }^{66}$ The NAACP Legal Defense and Educational Fund is currently leading similar challenges in other states. ${ }^{67}$ If these challenges succeed, increased minority voting power may contribute to the success of candidates who are more concerned with the fundamental fairness of the criminal justice system than merely appearing to be "tough on crime."

Reform efforts generally focus on the more sympathetic victims of errors in the criminal justice system-individuals "driving while black," or convicted of crimes they did not commit, or ex-felons who seek the right to vote as part of their reintegration into society rather than on structural reforms that identify and remedy the sources of disparity in criminal justice institutions. Advocates for justice rely on public education and community organization and advocacy, in addition to legislative and legal efforts. They struggle in

63. Id. at 43

64. See Jeff Manza \& Christopher Uggen, Locked Out: Felon Disenfranchisement and American Democracy (2006); Steven Ramirez \& Aliza Organick, Taking Voting Rights Seriously: Race and the Integrity of Democracy in America, 27 N. Ill. U. L. Rev. 427 (2007); George P. Fletcher, Disenfranchisement as Punishment: Reflections on the Racial Issues of Infamia, 46 UCLA L. Rev. 1895 (1999).

65. Ryan Paul Haygood, NAACP Legal Defense and Educational Fund, The Right to Vote Continues to Elude Millions (2005) http://www.naacpldf.org/ content.aspx?article $=563$ (arguing against felon disenfranchisement laws on grounds that they disproportionately exclude black and Latino communities from voting process despite decades-old efforts to ensure minority voting rights).

66. Farrakhan v. Washington, 359 F.3d 1116, 1116 (9th Cir. 2004); see also Voting Rights Act, 42 U.S.C. § 1973 (2007).

67. See NAACP Legal Defense and Educational Fund, Inc., Felon Disenfranchisement-Free the Vote, http://www.naacpldf.org/issues.aspx?sub context=40 (last visited Dec. 20, 2007) (describing cases in Alabama, Florida, and New York in which the Legal Defense Fund is litigating claims of racially discriminatory felon disenfranchisement statutes). 
the face of blatant dismissals of evidence of racial disparities-as in $\mathrm{McCl}$ eskey itself. They struggle to overcome the apathetic public and hostile courts, and the desensitizing banality of everyday race discrimination, ${ }^{68}$ but manage to force changes. For example, former U.S. Attorneys have recently acknowledged racial and ethnic disparities in the criminal justice system. ${ }^{69}$ They have begun to develop strategies to counter these problems and to address harsh punitive measures as "ineffective crime prevention." ${ }^{" 70}$ With support from prosecutors, advocates for social justice may be newly empowered to challenge the racial disparities highlighted by the Baldus Study.

\section{THE SYMPOSIUM}

We convened the Symposium on Pursuing Racial Fairness in Criminal Justice at Columbia Law School in March 2007 to draw lessons from current work on racial inequality in criminal law, and to design new strategies to pursue the goals of both the McCleskey litigation and the movement that surrounded the case. The participants included legal scholars, practitioners, researchers and activists who already had started the difficult analysis, mobilization, and theorizing to develop the foundation of new models of legal scholarship and civil rights advocacy to challenge McCleskey. The contributions in this Symposium are not naïve with respect to the formidable litigation-based challenges or the racial inequality that persists in the criminal law. Rather, they take on the task of building

68. See, e.g., Marianne Bertrand \& Sendhil Mullainathan, Are Emily and Greg More Employable than Lakisha and Jamal? A Field Experiment on Labor Market Discrimination (NBER Working Paper No. 9873, 2003), available at http://www.nber.org/papers/w9873 (showing evidence of racial discrimination toward job applicants with African-American names); Joseph Price \& Justin Wolfers, Racial Discrimination among NBA Referees (NBER Working Paper No. 13206, 2007), available at http://www.nber.org/papers/w13206 (showing that personal fouls are awarded more often against players when they are officiated by an opposite-race officiating crew than when officiated by an same-race refereeing crew, and that these biases are likely to affect the chances of winning for predominantly black teams).

69. Federal Sentencing Reporter, Prosecutorial Decision-Making and Racial/Ethnic Disparities in the Criminal Justice System: Principles and Guidelines, (2007), http://www.novembercoalition.org/stayinfo/breaking07/ BrennanGuidelines.html. Careful study is needed to assess whether these guidelines are practical, especially in the death penalty context.

70. Id. 
a diverse and empirically-informed strategy that looks critically into the institutional norms and designs of criminal justice agents. They begin to identify the moving parts of structural racialized decisionmaking that produce the enduring disparities we see today. The articles offer a sober and disturbing picture of racial discrimination in criminal justice.

The articles locate racial disparities in the institutional dynamics of criminal justice and in the racial skew of everyday decision-making. While McCleskey articulated a crime-control rationale for tolerance of error and refused to confront the racial disparities inherent in those errors, other decisions offered an affirmative argument for the institutionalization of racialized discretion in criminal justice. The decisions denying race-based claims in criminal law that began with McCleskey insulate criminal justice actors from constitutional claims by bowing to the discretion of decision-makers and celebrating the principle of faux blindness, or race-neutral professional judgment.

Beginning with Terry v. Ohio, ${ }^{71}$ deference to professional judgment and the carving out of a constitutionally-protected discretionary space were deemed essential to the interests of effective law enforcement. Few commentaries on Terry discuss its racial dimensions, yet Terry's calculus deeply embedded race in the subjectivity of official discretion. ${ }^{72}$ McCleskey, and later Armstrong, ${ }^{73}$

71. Terry v. Ohio, 392 U.S. 1, 21-22 (1968) (asserting that courts need to "evaluate the reasonableness of a particular search or seizure in light of the particular circumstances . . . anything less would invite intrusions upon constitutionally guaranteed rights based on nothing more substantial than inarticulate hunches"). It is hardly coincidental that the Terry opinion came in the midst of riots in the poorest, predominantly minority neighborhoods of 47 American cities, in a presidential election year when "law and order" became symbolic language to rally political support for harsher punishment for criminal offenders. See Report of the National Advisory Commission on Civil Disorder (1968), also referred to as the Kerner Commission Report.

72. Professor Anthony Thompson offered one of the very few analyses of Terry that made explicit its racial narrative. See Anthony Thompson, Stopping the Usual Suspects: Race and the Fourth Amendment, 74 N.Y.U. L. Rev. 956 (1999) (demonstrating how race has been excised from Fourth Amendment analysis and its harms); David Sklansky, Traffic Stops, Minority Motorists, and the Future of the Fourth Amendment, 1997 Sup. Ct. Rev. 271, 273 (1997) (concluding that recent Supreme Court law means "that police officers, if they are patient, can eventually pull over almost anyone they choose"). 
demanded a showing of specific racial animus by prosecutors to prove claims of racially selective prosecution. The impact of this was to create an unlighted space where discretion and subjective professional judgments could proceed with neither accountability nor recourse. Criminal justice institutions have had little incentive to address systemic racial discrimination, whether through the regulation of routinized decision-making, or through efforts to recast the institutional norms and preferences that shape those everyday decisions. ${ }^{74}$

The articles in this Symposium do not shrink from the difficult task of strategizing legal challenges to revive the pursuit of racial fairness throughout the criminal justice system. Instead, the authors identify the frontlines of a renewed struggle for the pursuit of racial fairness that was the heart of the McCleskey litigation.

Litigation remains an essential element of this work. Professor Anthony Amsterdam discusses the endemic racial discrimination that the courts have chosen to ignore, and shows how the arbitrariness of the death penalty rejected in Furman has reemerged since Gregg. ${ }^{75}$ McCleskey has shut off statistical analysis as a means to challenge racial discrimination in capital sentencing, but Amsterdam offers a method to mitigate McCleskey and to ultimately eradicate capital punishment altogether. ${ }^{76} \mathrm{He}$ encourages lawyers

73. United States v. Armstrong, 517 U.S. 456, 470 (1996) (requiring that defendants must produce "credible evidence" that similarly situated defendants of other races could have been prosecuted but were not).

74. Police officers function in organizational contexts where rewards and sanctions, both formal and social, shape their conduct. They want to advance, avoid discipline, and gain the respect of their superiors and peers. Accordingly, as rational actors in rational organizations, one institutional reform that could affect discretion is the use of incentives for model police behavior. See Erik Luna, Race, Crime, and Institutional Design, 66 Law \& Contemp. Probs. 183, 196 (2003) (discussing the possibility of such a reward structure). Although discretion is deeply embedded in criminal law doctrine, others have imagined how social science and technology can be put to work to narrow discretion and therefore avoid errors and biases. See, e.g., Elizabeth Joh, Discretionless Policing: Technology and the Fourth Amendment, 95 Cal L. Rev. 199 (2007); Bernard Harcourt, Against Prediction (2005).

75. Anthony G. Amsterdam, University Professor and Professor of Law at New York University School of Law, Opening Remarks at the NAACP Legal Defense and Educational Fund and Columbia Law School Symposium: Pursuing Racial Fairness in the Administration of Justice: Twenty Years After McCleskey v. Kemp (Mar. 2, 2007), in 39 Colum. Hum. Rts. L. Rev. 34 (2007).

76. Id. at 48 . 
and scholars to study the impact of race on capital sentencing patterns in Southern states, and to then do exhaustive research in the counties with the most egregious evidence of racial bias. ${ }^{77} \mathrm{He}$ argues that massive evidence of racial discrimination across several jurisdictions will change the terms of public and judicial opinion. ${ }^{78} \mathrm{He}$ urges a shift in focus from states to counties, where death sentences originate and where local contexts make them possible. ${ }^{79}$ County studies, aided by court-ordered discovery and evidence of the racially biased attitudes by prosecutors or law enforcement officials, will provide the strongest tools for such a challenge. ${ }^{80}$ As Professor Amsterdam notes, anecdotal evidence is "simply the tollbooth payment that gets us onto the beltway around McCleskey." program will expose the absurdity of McCleskey in assuming that Equal Protection only extends to the overt prejudice of an individual decision-maker as opposed to the cultural context of racial discrimination. ${ }^{82}$ Finally, lawyers should advance an argument that the discriminatory administration of capital punishment statutes requires their wholesale invalidation, ${ }^{83}$ drawing upon cases such as Yick Wo v. Hopkins ${ }^{84}$ to furnish the appropriate remedy. Given changing attitudes about the death penalty, such an effort might offer some hope for eventual wholesale invalidation of the current capital punishment regime.

Professor David Rudovsky argues for a litigation strategy to attack racial profiling at the "point of entry" into the criminal justice system, which is the period where selective enforcement perhaps is most transparent. ${ }^{85}$ Rudovsky cites the success of using statistical findings to eliminate racial profiling in several states and in customs enforcement, ${ }^{86}$ despite the cumulative disadvantages of Terry, Whren, and other cases that have eviscerated Fourth Amendment

\footnotetext{
77. Id. at 49 .

78. Id. at $50-51$.

79. $\quad$ Id. at 52 .

80. Id. at 53 .

81. Id. at 54 .

82. Id. at $55-56$.

83. Id. at $56-57$.

84. Yick Wo. v. Hopkins, 118 U.S. 356 (1886) (holding unconstitutional, on Equal Protection grounds, the discriminatory administration of an otherwise facially-neutral law).

85. Rudovsky, supra note 52, at $100-01$.

86. Id. at $102-06$.
} 
protections against racially-discriminatory police practices. ${ }^{87} \mathrm{He}$ argues that the Equal Protection Clause offers some remedies; and although changing political opinions since 9/11, combined with cases such as Armstrong and McCleskey, make such challenges difficult, statistical evidence has been particularly useful in challenging police officers' (as opposed to prosecutors') conduct. ${ }^{88}$ Civil litigation is more likely to provide systemic relief here, given the lack of an exclusionary rule for Fourteenth Amendment violations. ${ }^{89}$ Moreover, the success of the "innocence movement" in changing police procedures during investigation and interrogation offers new avenues to promote fairness for all defendants. ${ }^{90}$

Miriam Gohara's commentary elaborates on Rudovsky's approach for successful challenges to racial discrimination in criminal justice enforcement. Despite both the procedural obstacles created by a line of Supreme Court decisions that narrow the grounds upon which race-based claims can be brought, and restrictive legislation such as the Anti-Terrorism and Effective Death Penalty Act $^{91}$ and the Prison Litigation Reform Act ${ }^{92}$, Rudovsky highlights the success of some cases, like those attacking racial profiling, in focusing on ameliorating racial discrimination at the "point of entry" into the criminal justice system. ${ }^{93}$ Gohara argues that "point of entry" challenges have succeeded not only because of legislative action or consent decrees, but also due to the focus on state action which makes for more persuasive evidence of discrimination than the independent action of prosecutors and juries, which can cloud evidence of state Fourteenth Amendment violations. ${ }^{94}$

87. Id. at $106-07$.

88. Id. at $110-11$.

89. Id. at 113 .

90. Id. at $119-20$.

91. Antiterrorism and Effective Death Penalty Act (AEDPA) of 1996, Pub. L. No. 104-132, 110 Stat. 1214 (codified as amended in scattered sections of 8, 18, 28 \& 42 U.S.C. (2006)).

92. Prison Litigation Reform Act (PLRA) of 1995, Pub. L. No. 104-134, 110 Stat. 1321 (1996) (codified as amended in scattered sections of 11, 18, $28 \& 42$ U.S.C. (2006)).

93. Rudovsky, supra note 52, at 97.

94. Miriam S. Gohara, Commentary, Sounding the Echoes of Racial Injustice Beyond the Death Chamber: Proposed Strategies for Moving Past McCleskey, 39 Colum. Hum. Rts. L. Rev. 124, 135-36 (2007). 
She notes the example of a NAACP Legal Defense Fund challenge to the practice of arresting individuals who owed old fines to the City of Gulfport. ${ }^{95}$ Having appealing, sympathetic plaintiffs (which is more likely in a point-of-entry as opposed to a capital case) can better highlight the injustice of policies that discriminate on the basis of race and social class. ${ }^{96}$ Data produced by racial-profiling statutes and consent decrees have made the evidence of discrimination much more prominent. Gohara notes that empirical data can bolster anecdotal evidence of racial and socioeconomic discrimination, arguing that such evidence must be well-publicized to erode the "post-racial' illusion" courts have adopted since McCleskey. ${ }^{97}$ For Gohara, litigation strategies at all levels of government, complemented by education and public outreach programs, can help bolster an understanding of the discrimination that permeates the criminal justice system. ${ }^{98}$ She notes how the fiction of a post-racial world provides a space in which the legacies of racial discrimination continue unchallenged, as McCleskey and decisions such as Whren, ${ }^{99}$ Armstrong, ${ }^{100}$ and Wardlow ${ }^{101}$ demonstrate. McCleskey has virtually eliminated incentives to address racial discrimination in the death penalty since the challenge of the need for "smoking gun" evidence far outweighs any procedural gains from the grant of standing to defendants to bring race-of-victim claims. ${ }^{102}$ Despite Justice Powell's suggestion that such concerns be directed to legislative bodies, McCleskey bolstered antireform arguments. ${ }^{103}$ Gohara's article provides a litigation roadmap to reverse these trends.

95. Id. at $136-37$.

96. Id. at 137 .

97. Id. at 141. In this illusion, whites as individuals and Americans collectively are morally obligated to ignore the distinctions of racial minorities from the whole, and race consciousness in law is a form of bias that leads to the perpetuation of disadvantage. See Taslitz, supra note 2.

98. Gohara, supra note 94, at 141-42.

99. Whren, 517 U.S. at 814 (holding that a police officer's subjective reasons for stopping a car are not relevant when determining the reasonableness of that stop under the Fourth Amendment).

100. Armstrong, supra note 73.

101. Illinois v. Wardlow, 528 U.S. 119, 124-25 (2000) (holding that police can consider characteristics of a high crime location in determining whether behavior rises to the level of suspicion that warrants further investigation).

102. Baldus, supra note 27, at 144. See also Pa. Supreme Court Comm. on Racial \& Gender Bias in the Justice System, supra note 55.

103. Baldus, supra note 27, at 145. 
Proportionality remains a concern of legislative bodies, despite the evisceration of proportionality as a basis for a constitutional claim. Professors David C. Baldus, George Woodworth, and Catherine M. Grosso examine proportionality evidence from Pennsylvania, Maryland, and New Jersey. Thanks to a recent set of studies, Pennsylvania has McCleskey-like evidence of racial disparities (with regard to the race of defendants rather than victims), although its Supreme Court has not decided any cases on the merits by relying on this evidence. ${ }^{104}$ Maryland's governor commissioned a study of the death penalty that revealed evidence of systemic disparities in black-defendant/white-victim cases. ${ }^{105}$ Despite such evidence, and over a dissent arguing that the disparity was enough to trigger Armstrong discovery rights, the Maryland Court of Appeals ultimately adopted a McCleskey-like approach because of the absence of convincing evidence of discrimination by a prosecutor or jury in any individual case. ${ }^{106}$

The New Jersey Supreme Court developed an empirical database that includes all cases, and has rejected McCleskey's onerous burden of proof. ${ }^{107}$ While it has not ruled in favor of any plaintiffs' claims of systemic discrimination, the New Jersey Supreme Court has taken a much more proactive stance to ensure the proportionate and consistent application of the death penalty. ${ }^{108}$ A decision in 1987 prompted county prosecutors to adopt capital charging guidelines, a decision in 1989 established a rigorous framework of monitoring, and a decision in 1992 rejected McCleskey's "direct evidence of purposeful discrimination" requirement. ${ }^{109}$ While the New Jersey court has actively monitored race-based claims andprior to its 2007 abolition-reserved the death penalty for the most aggravated cases, the fact that it has denied all claims of systemic discrimination does not mean that the system is cured of race-based effects. ${ }^{110}$ Rather, other more troubling factors may weigh into this

104. Id. at $152-54$.

105. Id. at 159. See also Paternoster et al., supra note 26.

106. Id. at 163-64. See, e.g., Evans v. State, 914 A.2d 25, 66-67 (Md. 2006) (holding that general statewide statistics cannot establish a violation of the Maryland Declaration of Rights; the defendant must establish specific discriminatory intent in his case).

107. Id. at $166-67$.

108. Id. at 164-65. See N.J. Const. art. 1, § 12.

109. Baldus, supra note 27, at 166-67.

110. Id. at $169-70$. 
result, such as the fact that the Court has limited indirect evidence of discrimination and has adopted a high burden of proof - on the order of that required in McCleskey. ${ }^{111}$ Nevertheless, the Court's attention encouraged prosecutorial vigilance to avoid the taint of racism on capital sentences.

Race-of-victim effects persisted despite such efforts in New Jersey, raising questions about the ability of any system with broad statutory aggravating factors to purge the system of race effects. Moreover, given the unusual independence granted to Supreme Court justices in New Jersey, this model might not be replicable in states with elected justices. Therefore, Baldus argues, either total abolition or a drastic narrowing of death-eligible crimes is essential to reduce systemic racial discrimination in capital punishment. ${ }^{112}$

Professor Sheri Lynn Johnson proposes that new social science research on subconscious racial bias can be put to work to redesign the process of fact-finding and trial strategies. ${ }^{113}$ Unconscious biases may animate racial associations and emotions that then become engines of cognitive bias, ${ }^{114}$ which in turn may create perceptions and emotions that cast African-American defendants as more culpable and therefore "deathworthy" ${ }^{115}$ Using these dynamics in jury selection and trial strategy can reveal and redirect the underlying racial frames of jurors and judges. She shows the need for greater diversity among fact-finders and a focus on individualized relief. ${ }^{116}$ Johnson cautions that although only one McCleskey claim has succeeded in the last twenty years, ${ }^{117}$ and that case involved a black-on-black murder, in other cases racial disparity evidence may have led courts to be more receptive to other unfairness claims. ${ }^{118}$ She uses Batson v. Kentucky ${ }^{119}$ to imagine how more diverse

111. Id. at 169 .

112. Id. at 177 .

113. Johnson, supra note 45, at 190. See, e.g., Christine Jolls \& Cass R. Sunstein, The Law of Implicit Bias, 94 Cal. L. Rev. 969, 982-86 (2006) (discussing the possibility that workplaces that promote positive depictions of minorities and that are diverse may decrease implicit bias and therefore lessen workplace discrimination).

114. Johnson, supra note 45, at 189.

115. Id. at 198; Eberhardt et al., supra note 15.

116. Johnson, supra note 45 , at 178.

117. Id. at $179-80$.

118. Id. at $184-85$.

119. Batson v. Kentucky, 476 U.S. 79 (1986). 
juries can mitigate the effects of implicit and unconscious racial bias. $^{120}$

Professor Angela Davis presents a framework for understanding and addressing race and class disparities arising from prosecutorial discretion. Such discretion is the root of many of the unwarranted racial disparities in the American criminal justice system. ${ }^{121}$ Even though most individual prosecutors are not deliberately racist, race and class influence every stage of the criminal justice system, contributing to disparate outcomes. ${ }^{122}$ For example, because "[r]ace often plays a role in the decision to detain and/or arrest a suspect", a black defendant may be labeled a recidivist when a "more criminal" white defendant will be treated as a first-time offender deserving of leniency. ${ }^{123}$ Davis argues that, although the Supreme Court has ensured that no legal remedies are available, prosecutors must take responsibility for the racial impact of their decisions. ${ }^{124}$

Synthesizing Oyler v. Boles, Washington v. Davis, and Wayte $v$. United States, Davis concludes that both discriminatory effect and purpose must be shown to prove selective prosecution. ${ }^{125}$ Moreover, the United States $v$. Armstrong ${ }^{126}$ ruling sets an onerous threshold for discovery in a selective prosecution case-a burden that most resource-constrained defendants will likely be unable to meet. ${ }^{127}$ Similarly, the McCleskey decision is a symptom of the Court's "aversion to challenging the exercise of prosecutorial discretion." 28 Given this aversion even in the face of pervasive evidence, reform must be pursued outside of litigation. In particular, Davis argues that racial impact studies should be conducted in prosecutors' offices. These studies should track the race of the defendant and victim at each step of the process. ${ }^{129}$ The public dissemination of the results of such studies would help motivate prosecutors to correct inequities

120. Johnson, supra note 45, at 185-86.

121. Angela J. Davis, Racial Fairness in the Criminal Justice System: The Role of the Prosecutor, 39 Colum. Hum. Rts. L. Rev. 202, 202-03 (2007).

122. Id. at 203.

123. Id. at 209-10.

124. Id. at 210.

125. Id. at 211 .

126. United States v. Armstrong, 517 U.S. 456 (1996).

127. Davis, supra note 121, at 214.

128. Id. at 217.

129. Id. at 219-20. 
and enable voters to elect prosecutors who care about eliminating racial bias. ${ }^{130}$ Davis also endorses an ABA Commission recommendation to form Criminal Justice Racial and Ethnic Task Forces to gather and disseminate social science and public policy evidence on racial fairness in the administration of criminal justice. ${ }^{131}$ Acknowledging that there will be prosecutorial resistance, Davis suggests ways to make the data collection requirements less onerous. She also offers the Vera Institute of Justice's Prosecution and Racial Justice Project as a model approach to reducing racial bias at every stage of the prosecutorial process. ${ }^{132}$ Above all, Davis emphasizes that prosecutorial cooperation will be crucial in eliminating unwarranted racial disparities in the criminal justice system. ${ }^{133}$

Legislation is the focus of two articles in this Symposium. Professor Olatunde Johnson's contribution cites statements by the U.S. Supreme Court as to its institutional incompetence to effectively address disparate impact claims. ${ }^{134}$ While noting the fundamental dilemma - that legislatures' apathy towards these issues explains why advocates have tried the courts-she recognizes that the Court's decisions have left few options.

Johnson first recounts the failure of a federal Racial Justice Act (RJA) to effectively overturn the McCleskey ruling. The RJA, first proposed in 1988, sought to allow the use of statistics to shift the burden of proof to demonstrate that racial disparities were "clearly and convincingly' explained by nondiscriminatory factors." 135 Later versions, including the RJA that was added to the 1994 crime bill that passed the House, imposed a reduced burden of proof and eliminated state data collection requirements. Nonetheless, even these concessions failed to convince those who felt the RJA would

130. Id. at $221-22$.

131. Id. at $222-23$.

132. Id. at $228-29$.

133. Id. at 232 .

134. Olatunde C. A. Johnson, Legislating Racial Fairness in Criminal Justice, 39 Colum. Hum. Rts. L. Rev. 233, 233 (2007) (pointing out that the Court states that "McCleskey's arguments are best presented to the legislative bodies" and that "it is not the responsibility—or indeed even the right—of this Court to determine the appropriate punishment for particular crimes") (citing McCleskey v. Kemp, 481 U.S. 279, 319 (1987)); see Washington v. Davis, 426 U.S. 229 (1976); Pers. Adm'r of Mass. v. Feeney, 442 U.S. 256 (1979).

135. Johnson, O., supra note 134, at 238-39 (citing H.R. 4442 § 3(c)). 
impede the execution of capital punishment. ${ }^{136}$ She then turns to the Kentucky Racial Justice Act (KRJA), ${ }^{137}$ which has been the only state law to explicitly address the reality of racial disparity in criminal justice. But this weak law had a low standard of proof for the state and only concerned discrimination by prosecutors in choosing to seek the death penalty. ${ }^{138}$ The KRJA's success seems limited at best, and some anecdotes suggest that the law has had the perverse consequence of encouraging prosecutors to seek a death sentence in even more cases. Johnson then discusses some other forms of review, like state commissions and the (now defunct) New York death penalty law, which explicitly included evidence of racial bias in its proportionality review. ${ }^{139}$

Johnson discusses the recent legislative reform movement to impose moratoriums or to abolish outright the death penalty in certain states (even as efforts to expand it continue in other states). While racial inequalities have played a role in some states, such as in Maryland's moratorium, concerns about the potential innocence of some death row inmates have also featured prominently in reform efforts and the overall decline in support for capital punishment.

Johnson then extends her discussion to racial fairness and sentencing reform beyond the death penalty context, focusing particularly on drug offenses. The concentration of resources on particular types of policing activity may largely be responsible for high minority incarceration rates. Highlighting a recurring theme of unresponsiveness to progressive calls for reform-as demonstrated by congressional inaction in reducing the sentencing disparity between crack and powder cocaine-she notes the promise of state drug law reform. Yet despite many states' drug law reforms, these efforts often arise over concerns about the efficacy of punitive drug laws rather than the racially disparate impact of harsh sentences. While she appreciates an effort in Oregon to consider "racial impact statements" in criminal justice sentencing, assumptions about high minority criminality may likely make such explicitly race-based reform efforts less successful.

There are further limitations to using racial disparity as a focus for criminal justice reform. Race-based reform efforts may help

136. Id. at $240-41$.

137. Ky. Rev. Stat. Ann. § 532.300-309 (West 1998).

138. Id.

139. Johnson, O., supra note 134, at 244. 
spur change, but the changes may ultimately be deracialized by ignoring the racial imbalances that were the target of the corrective amendments. For example, in Kimbrough, the Supreme Court upheld sentencing departures from the Federal Sentencing Guidelines for crack cocaine offenses, but only twice in the decision mentioned the racial dimensions of the infamous 100-to-1 crack-powder cocaine disparity, and then only in passing via a secondary citation to a five year old report from the U.S. Sentencing Commission.140 And, in Connecticut, the state legislature eliminated the crack-powder cocaine disparity without mentioning the racial impacts of the state's repealed law. Like the Federal Sentencing Commission and the Kimbrough court, the Connecticut legislature cited new social facts disputing the allegedly greater harms of crack cocaine, barely recognizing the racial imbalances in the administration of these

140. See Kimbrough v. United States, 128 S.Ct. 558 (2007) (upholding a trial judge's downward departure from the Federal Sentencing Guidelines for a defendant who pled guilty in 2005 to possession of 56 grams of crack cocaine, stating that crack and powder cocaine merit equal treatment and rejecting the higher federal sentences for trafficking crack cocaine). See also Linda Greenhouse, Justices Restore Judges' Control Over Sentencing, N.Y. Times, Dec. 11, 2007, at A1. Justice Ginsburg, writing for the Kimbrough majority, noted that the U.S. Sentencing Commission's action to reduce the crack-cocaine sentencing disparity was based on its finding that the "problems associated with the 100-to-1 drug quantity ratio [are] urgent and compelling, and that the higher penalties for crack cocaine far "overstate" both "the relative harmfulness" of crack cocaine and the "seriousness of most crack cocaine offenses." Kimbrough, 128 S.Ct. at 9. See also United States Sentencing Commission, Report to Congress: Cocaine and Federal Sentencing Policy 8 (May 2007), available at http://www.ussc.gov/ r_congress/cocaine2007.pdf. The Commission promulgated the guideline amendment as a measure to alleviate some of the problems noted by Justice Ginsburg. The Commission also recommended that Congress take further steps to reduce the sentencing disparity in federal law. The lengthy Kimbrough opinion mentioned race only twice. First, the majority cited the Commission's 2002 report that recognized and criticized the crack/powder sentencing differential as "foster[ing] disrespect for and lack of confidence in the criminal justice system" because of a "widely-held perception" that it "promotes unwarranted disparity based on race." United States Sentencing Commission, Report to Congress: Cocaine and Federal Sentencing Policy 103 (May 2002), available at http://www.ussc.gov/r_congress/02crack/2002crackrpt.pdf. Second, the majority cited the statements in the 2002 Report that approximately $85 \%$ of defendants convicted of crack offenses in federal court are black; thus the severe sentences required by the 100-to- 1 ratio are imposed "primarily upon black offenders." Kimbrough, 128 S.Ct. at 9, 15. 
laws. ${ }^{141}$ More generally, a focus on racial politics detracts from the larger issue of America's "over-reliance on incarceration" as well as the need to forge coalitions to address criminal justice reform-even though racial subjugation is an implicit aspect of harsh sentencing policies. ${ }^{142}$

Professor Dorothy Roberts emphasizes the need for a full understanding of the extent of racial oppression before seeking to rectify the problem through a concerted campaign toward abolition of a broad set of racially destructive laws and policies. McCleskey and cases requiring individualized proof of racial discrimination "treat[] racial bias as a system malfunction" when the criminal justice system is designed to subjugate African Americans. ${ }^{143}$ She notes that the McCleskey decision recognized that a different decision would threaten the entire criminal justice system, given how pervasive racial bias is in the system. ${ }^{144}$

Roberts contends that mass incarceration, capital punishment, and police terror are the direct progeny of slavery and Jim Crow. ${ }^{145}$ "[M]ass imprisonment of African Americans should be viewed as a state measure to supervise citizens en masse on the basis of race rather than a race-neutral effort to control crime or mete out offenders' just deserts," especially in light of the fact that "stable incarceration rates appear in a period of white hegemony and a stable racial order" and spikes in minority incarceration rates occur during times of upheaval in the racial hierarchy. ${ }^{146}$ Capital punishment and police terror more generally have their origins in the lynchings of previous epochs, designed to reassert white dominance. ${ }^{147}$ Roberts concludes the entire criminal justice system is a vehicle for the reinforcement of racial hierarchy and control.

141. 13 states had similar disparities as of 2005 , but only Connecticut has acted legislatively to eliminate the disparity. See HB 6975, available at http://www.cga.ct.gov/2005/ACT/Pa/pdf/2005PA-00248-R00HB-06975-PA.pdf, enacting Public Act No. 05-248, ended the sentencing disparity between crack and powder cocaine effective July 1, 2005.

142. Johnson, O., supra note 134, at 256.

143. Dorothy Roberts, Constructing a Criminal Justice System Free of Racial Bias: An Abolitionist Framework, 39 Colum. Hum. Rts. L. Rev. 261, 264 (2007).

144. Id

145. Id. at 267 .

146. Id. at $271-72$.

147. Id. at $274-75$. 
Abolition of all these forms of racist control is necessary for any lasting change to occur.

Theodore Shaw, whose vision inspired and animated the Symposium, also paints a rich and detailed picture of the dynamics of racial inequality. He begins by arguing that the Supreme Court has applied a "gratuitously cramped constitutional jurisprudence" to racial discrimination claims by minorities. Shaw notes that desegregation jurisprudence adopted a de facto/de jure distinction not found anywhere in the Constitution. He cites the intentionality requirement of Washington $v$. Davis ${ }^{148}$ as an example of how courts have washed their hands of "societal discrimination". ${ }^{49}$ Courts have been much more receptive, however, to equal protection arguments brought by whites in "reverse discrimination" affirmative action and gerrymandering cases.

In particular, "McCleskey $v$. Kemp stands out as a decision [that] has erected a barrier to challenging" discriminatory policies. ${ }^{150}$ Subsequent studies have shown that the Baldus Study ${ }^{151}$ was not an anomalous result. Continued disparities in capital punishment, particularly in "lynching states," are the result of the willful ignorance of McCleskey. ${ }^{152}$ The impact of the War on Drugs on minority communities offers further evidence of the racial bias that permeates the criminal justice system, and of the willingness of judges to tolerate disparities. ${ }^{153}$ Even in the face of this discouraging situation, however, Shaw implores his listeners to maintain hope and to act to create a more just reality. ${ }^{154}$

The historical trajectory leading to McCleskey shows the inevitability of a constitutional conflict from two strains in American law and society that had been building for decades. Robert Stroup

148. Washington v. Davis, 426 U.S. 229 (1976) (upholding a law in spite of its racially disproportionate impact because it lacked a racially discriminatory purpose).

149. Theodore M. Shaw, Director-Counsel and President of the NAACP Legal Defense and Educational Fund, Inc., Keynote Address at the NAACP Legal Defense and Educational Fund and Columbia Law School Symposium: Pursuing

Racial Fairness in the Administration of Justice: Twenty Years After McCleskey

v. Kemp (Mar. 3, 2007), in 39 Colum. Hum. Rts. L. Rev. 59, 61 (2007).

150. Id. at 66 .

151. Baldus Study, supra note 5.

152. Shaw, supra note 149 , at 68 .

153. Id. at 69 .

154. Id. at $72-73$. 
begins this history with a detailed recounting of the trial that led to the Supreme Court case. The McCleskeys hired a private lawyer to defend their son Warren, but had no money to provide a thorough defense. ${ }^{155}$ McCleskey's childhood, the murder, and the trial all occurred in a context of rampant segregation, discrimination, and economic disparities in the American South of the 1960s and 1970s. As a result of residential segregation, the McCleskey jury included eleven Whites and one Black, most of whom presumably lived in areas with limited racial intermixing. ${ }^{156}$ After McCleskey's conviction, the appeals process took place during the Reagan era. During this time of growing income inequality, social welfare support and legal services for indigent criminal defendants weakened, further hurting poor Americans, with a disproportionate impact on African Americans. ${ }^{157}$ During the early 1980s when McCleskey's appeals proceeded, President Reagan wanted judges to be more concerned about society than criminal rights, and sought more punitive punishments while simultaneously escalating the War on Drugs. ${ }^{158}$

Stroup also provides a legal context for the decision. He explains that advocates had hope of success when the Court granted certiorari, given the several "liberal" victories in the October 1985 Term, which upheld affirmative action and voting rights while permitting the use of statistical evidence to prove racial discrimination. ${ }^{159}$ Given these decisions, a McCleskey victory seemed possible. ${ }^{160}$ However, the Court "lacked the will" to enforce the Fourteenth Amendment because of the upheaval that a ruling for McCleskey might cause, and not just in criminal law and

155. Stroup, supra note 32 , at 78-79.

156. Id. at 79-80.

157. Id. at 80 .

158. Id. at 83,86

159. See Local 93 v. Cleveland, 478 U.S. 501 (1986) (upholding consent decree that employed affirmative action for minorities who were not victims of discrimination); Thornburg $v$. Gingles, 478 U.S. 30 (1986) (holding that North Carolina multimember legislative districts dilute minority votes in violation of the Voting Rights Act); Vasquez v. Hillery, 474 U.S. 254, 259-60 (1986) (holding that exclusion of African Americans from grand jury required overturning of conviction that resulted from that indictment and accepting use of "general statistical principles" to determine racial discrimination in criminal justice context).

160. Stroup, supra note 32 , at 93. 
procedure. ${ }^{161}$ Stroup's detailed recounting of the social and historical context of the era calls attention to the present. The same forces which existed at the time of McCleskey exist today. These forces are related to race and criminal law, along with pervasive racial disparities in housing, education, health care, and other domains of law and social policy. Stroup's history of the McCleskey era illuminates the present as the staging ground for the next era of litigation and political struggle.

\section{CONCLUSION}

The articles in this Symposium offer a set of connected frameworks for a renewal of legal advocacy and scholarship to address the principles of racial justice. The product of interactions between legal scholars, civil rights advocates, litigation experts, and empirical researchers, the richly nuanced articles that follow present a wide range of thoughtful and passionate approaches to the challenge of McCleskey. The authors offer innovative ways to address the problem of racial bias in criminal justice. Some cite the need for continued rigorous studies to offer clear evidence of disparate racial impact that might create sufficient media outrage to warrant legislative or judicial changes. Others cite the Kentucky Racial Justice Act ${ }^{162}$ or the New Jersey Supreme Court's efforts to reduce racial impact ${ }^{163}$ as models, although the results of those efforts have been mixed at best, and political conditions preclude those models from being adopted more widely. Although the authors' positions range from cautious hope to pessimism, they share a desire to force this country to consider the implications of racial disparities that derive from a long history of racial subjugation, if not from racial animus in some individual cases. With the implicit toleration of racial discrimination by the Supreme Court, however, the McCleskey decision impedes the ability of advocates to convince other stakeholders to use their efforts to ensure a more race-neutral

161. Id. at 96 .

162. Ky. Rev. Stat. Ann. § 532.300-309 (West 1998).

163. N.J. Stat. Ann. § 2C:11-3(e) (1978) (requiring the Supreme Court to decide whether each death sentence was applied fairly: "Every judgment of conviction which results in a sentence of death under this section shall be appealed, pursuant to the Rules of Court, to the Supreme Court. Upon the request of the defendant, the Supreme Court shall also determine whether the sentence is disproportionate to the penalty imposed in similar cases, considering both the crime and the defendant"). 
criminal justice system. The Symposium begins the process of building an architecture of law, policy, social science, and legal and civil rights advocacy to reverse the legacy and burden of McCleskey, which will, with hope, spark new analyses, strategic debate, and action on a variety of fronts. 